\title{
Food access and consumption in a rural settlement in Castanhal, PA, Brazil
}

\author{
Riziane Duarte PORTAL ${ }^{1 \star}$, Suely Cristina Gomes de LIMA ${ }^{1}$, Maria Regina S. Peixoto JOELE ${ }^{1}$
}

\begin{abstract}
The study aimed to assess the food accessibility and consumption among families in the Cupiúba rural settlement, in the city of Castanhal, Pará, Brazil. It was found that the access to food is worrying and indicated that most families are in food insecurity conditions. Moreover, income and food safety level were associated. The consumption of the settler families comprises mainly high-energy, low-nutrient content foods, characterized by the low intake of fruits and vegetables and the introduction of processed foods with high energy density and sugar-added beverages, although the traditional dietary habits (rice and beans) are still present. This configures a diet at risk for important nutritional deficits, obesity, and many non-communicable chronic diseases.
\end{abstract}

Keywords: access; food consumption; settlement.

Practical Application: Most families studied are in food insecurity conditions and food consumption comprises mainly high-energy, low-nutrient content foods, characterized by the low intake of fruits and vegetables and the introduction of processed foods with high energy density and sugar-added beverages, although the traditional dietary habits (rice and beans) are still present. This configures a diet at risk for important nutritional deficits, obesity, and many non-communicable chronic diseases.

\section{Introduction}

The enforcement of the Direito Humao à Alimentação Adequada - DHAA (Human Right to Adequate Food - HRAF) enables the dignified obtainment of Food and Nutrition Safety (FNS) and the freedom to fulfill other fundamental rights (Burity et al., 2007).

FNS is defined as the fulfillment of the widespread right to regular and permanent access to quality foods, at sufficient amounts, with no harm to the access to other essential needs, based on healthful dietary practices that respect cultural diversity and that are socially, economically, and environmentally sustainable (Brasil, 2006).

In rural areas, the access to food may be fully or partially guaranteed by the production for on-farm consumption. This production is very common in family agriculture and is an important strategy for FNS, whose basic requirement is guaranteeing food at the table. However, this agriculture has been undergoing significant transformations with a progressive orientation towards the market, monoculture, and specialization, thus neglecting subsistence crops, since much of the food lately has been bought and not produced on-site (Balem \& Silveira, 2005).

The dimension of the FNS concept regarding the guarantee of regular access to quality foods was the main focus of the present study. Besides the biological, sanitary, and technological matters, quality involves nutrition, which is the aspect approached by this research. Thus, only two aspects of the FNS concept were approached: Access to food and nutritional quality, aiming to evaluate the accessibility to foods through the Escala Brasileira de Insegurança Alimentar - EBIA (Brazilian Scale of Food
Insecurity - BSFI) and to qualitatively analyze food consumption among agricultural families in the rural settlement of Cupiúba.

\section{Materials and methods}

\subsection{Research site and design}

The Cupiúba Settlement Project is located in the city of Castanhal and features 237 plots with 232 settled families. The research comprehended all 232 families living in the settlement, who answered a questionnaire to evaluate the food accessibility and consumption.

\subsection{Ethical aspects}

The study was approved by the Research Ethics Committee of the Centro Universitário do Estado do Pará - CESUPA - and only the families that signed the term of free and informed consent took part in the research. The president of the association that represents the settlement was asked for written permission for the research.

\subsection{Data collection}

Data were collected through household visits in the settlement. The questionnaire consisted of questions from the Escala Brasileira de Insegurança Alimentar - EBIA (Brazilian Scale of Food Insecurity - BSFI) and inquiries about the socioeconomic conditions, dietary and production profiles, and dietary frequency. 
The Escala Brasileira de Insegurança Alimentar - EBIA (Brazilian Scale of Food Insecurity - BSFI) is a SAN assessment tool at family level and suitable for making a diagnosis of food insecurity, indicate populations most at risk and, if used along with appropriate indicators, also for the monitoring and evaluation of population impact of programs and policies. For Corrêa et al. (2004) it is a tool with excellent cost-effectiveness that has been used since the 1990 in several countries, and whose application and analysis have demonstrated common aspects to the different socio-cultural contexts and representing the degree of severity of food insecurity.

Only one adult subject (over 18 years old) able to answer about the family's daily life and about the other family members was interviewed per household or plot.

The families were visited with no prior warning, so some might not be found in the first visit. In this case, or in case no family member over 18 years old was found, the family was visited two more times on different days and times from the first visit. After the third visit with no contact, the family was considered a lost plot.

\subsection{Statistical analysis}

The data were analyzed using the softwares Microsoft Office Excel 2010 to store the data and create the graphs and/or tables with percentages and Bioestat 5.0 (2007) to apply the statistical tests (G-test of independence).

\section{Results and discussion}

Of the 232 settler families, 185 were interviewed, i.e., a loss of $20.2 \%$ (47) due to families or family members over 18 years old that were not found at home after three attempts. It was found that nearly all (95.1\%) families did not produce most of the food required to sustain the family and that $63.2 \%$ purchase their food mainly in supermarkets.

Figure 1 shows that $42.2 \%$ (78) of the families were in the food safety conditions. However, $57.8 \%$ (107) of the families were in food insecurity (FI) conditions, split as $44.3 \%$ (82) at mild, $8.6 \%(16)$ at moderate, and $4.9 \%(9)$ at severe FI.

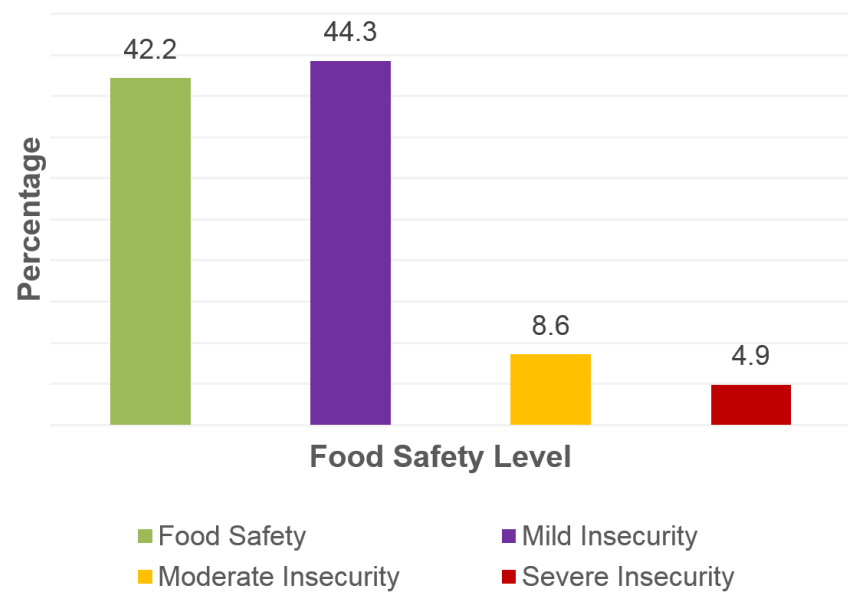

Figure 1. Food safety levels in Cupiúba Settlement, Castanhal, PA, Brazil, 2014.
The food insecurity reality found in the present study is not an isolated fact, but rather a situation that affects many settlements in the different regions of Brazil. Such results match a study carried out by Dombek (2006) in three rural settlements in the state of São Paulo, Brazil, which found that $58.8 \%$ of the families were at various levels of food insecurity situations. Of those, $40.7 \%$ were in mild food insecurity, $14.1 \%$ were in moderate food insecurity, and $4.0 \%$ were in severe food insecurity. The other $41.1 \%$ of the families were in food safety conditions.

Food safety data reported by the supplementary survey of the 2009 National Household Sample Survey (PNAD) revealed that the number of Brazilian households at some level of food insecurity decreased from $34.9 \%$ to $30.2 \%$ between 2004 and 2009. The survey also found that food insecurity was more widespread in the North and Northeast regions, affecting $40.3 \%$ and $46.1 \%$ of the households, respectively. Rural areas had household FI prevalences above those found in urban areas both in 2004 and 2009. The numbers in urban areas dropped from $33.3 \%$ to $29.4 \%$ and from $43.6 \%$ to $35.1 \%$ in rural areas (Instituto Brasileiro de Geografia e Estatística, 2010). In 2013, the survey reported 65.3 million private households in Brazil, of which 50.5 million (77.4\%) were in food safety conditions. The FI prevalences in rural areas were also higher than those in urban areas: While $6.8 \%$ of the urban households had dwellers in moderate or severe FI situation, this proportion was $13.9 \%$ in rural areas (Instituto Brasileiro de Geografia e Estatística, 2014).

The present study found a statistically significant association between income and food safety level $(\mathrm{p}<0.05)$. Such findings match what would be expected: More underprivileged families had higher FI prevalence, with a direct association between family income and FI. Other studies also found this association (Souza et al., 2012; Santos et al., 2010).

Table 1 shows the frequency of the consumption of different food groups. The strong presence of carbohydrate sources is observed in the diets of these families, particularly the group of rice and pasta (mainly rice according to the interviews), which are consumed by $91.4 \%$ of the families at least twice a day, besides the group of bread, cake, cookies, tapioca cake, and tapioca, which are consumed daily by $47.6 \%$ of the families. The group of leguminous plants also stands out, with beans being consumed daily by $42.2 \%$ and twice a day by $49.2 \%$ of the families.

These results match the typical Brazilian diet, which comprises several influences and is currently strongly characterized by a combination of a so-called "traditional" diet (based on rice and beans) and foods classified as ultra processed with high fat, sodium, sugar, and calorie contents and low micronutrient content (Brasil, 2012).

The basic Brazilian diet is marked by the consumption of coffee and rolls, besides rice, beans and beef, natural and industrialized juices and sodas, and small amounts of fruits and vegetables. Some foods have a strong regional character, such as cassava flour in the North region. This dietary standard is compatible with the increase in overweight and metabolic disorder rates that have permeated the country's epidemiological and nutritional scenario (Souza et al., 2013). 
Table 1. Frequency (\%) of the food consumption reported by the families. Cupiúba Settlement, Castanhal, PA, Brazil, 2014.

\begin{tabular}{|c|c|c|c|c|c|c|}
\hline \multirow{3}{*}{ Food } & \multicolumn{6}{|c|}{ Food consumption frequency } \\
\hline & Never & Rarely & $1 / \mathrm{wk}$ & $2-4 /$ wk & Daily & $2+/$ day \\
\hline & \multicolumn{6}{|c|}{$\mathrm{n} / \%$} \\
\hline Rice, pasta & $0(0.0 \%)$ & $0(0.0 \%)$ & $0(0.0 \%)$ & $2(1.1 \%)$ & $14(7.6 \%)$ & $169(91.4 \%)$ \\
\hline Bread, cake, cookies, tapioca cake, tapioca & $0(0.0 \%)$ & $4(2.2 \%)$ & $6(3.2 \%)$ & $26(14.1 \%)$ & $88(47.6 \%)$ & $61(33.0 \%)$ \\
\hline Cakes and sandwich cookies & $1(0.5 \%)$ & $91(49.2 \%)$ & $45(24.3 \%)$ & $39(21.1 \%)$ & $8(4.3 \%)$ & $1(0.5 \%)$ \\
\hline Potato, cassava, yam, taro & $0(0.0 \%)$ & $23(12.4 \%)$ & $65(35.1 \%)$ & $84(45.4 \%)$ & $12(6.5 \%)$ & $1(0.5 \%)$ \\
\hline Cassava flour and other flours & $1(0.5 \%)$ & $2(1.1 \%)$ & $3(1.6 \%)$ & $4(2.2 \%)$ & $25(13.5 \%)$ & $150(81.1 \%)$ \\
\hline Leafy greens & $0(0.0 \%)$ & $11(5.9 \%)$ & $21(11.4 \%)$ & $81(43.8 \%)$ & $52(28.1 \%)$ & $20(10.8 \%)$ \\
\hline Legumes (pumpkin, carrot) & $0(0.0 \%)$ & $10(5.4 \%)$ & $23(12.4 \%)$ & $93(50.3 \%)$ & $53(28.6 \%)$ & $6(3.2 \%)$ \\
\hline Fruits, natural juice & $0(0.0 \%)$ & $7(3.8 \%)$ & $8(4.3 \%)$ & $75(40.5 \%)$ & $82(44.3 \%)$ & $13(7.0 \%)$ \\
\hline Beans and other leguminous plants & $0(0.0 \%)$ & $2(1.1 \%)$ & $4(2.2 \%)$ & $10(5.4 \%)$ & $78(42.2 \%)$ & $91(49.2 \%)$ \\
\hline Açaí, peach palm & $0(0.0 \%)$ & $161(87.0 \%)$ & $11(5.9 \%)$ & $7(3.8 \%)$ & $6(3.2 \%)$ & $0(0.0 \%)$ \\
\hline Milk, cheese, yoghurt & $0(0.0 \%)$ & $6(3.2 \%)$ & $3(1.6 \%)$ & $32(17.3 \%)$ & $90(48.6 \%)$ & $54(29.2 \%)$ \\
\hline Eggs & $0(0.0 \%)$ & $10(5.4 \%)$ & $45(24.3 \%)$ & $93(50.3 \%)$ & $34(18.4 \%)$ & $3(1.6 \%)$ \\
\hline Meat (beef, pork) & $0(0.0 \%)$ & $2(1.1 \%)$ & $11(5.9 \%)$ & $126(68.1 \%)$ & $39(21.1 \%)$ & $7(3.8 \%)$ \\
\hline Fish and seafood & $0(0.0 \%)$ & $97(52.4 \%)$ & $59(31.9 \%)$ & $28(15.1 \%)$ & $1(0.5 \%)$ & $0(0.0 \%)$ \\
\hline $\begin{array}{l}\text { Canned foods (sardines, tuna, frankfurter, } \\
\text { pickles, peas, corn) }\end{array}$ & $5(2.7 \%)$ & $90(48.6 \%)$ & $60(32.4 \%)$ & $28(15.1 \%)$ & $2(1.1 \%)$ & $0(0.0 \%)$ \\
\hline Poultry (chicken, duck) & $0(0.0 \%)$ & $12(6.5 \%)$ & $19(10.3 \%)$ & $131(70.8 \%)$ & $22(11.9 \%)$ & $1(0.5 \%)$ \\
\hline Offal and giblets (liver, kidney, heart) & $5(2.7 \%)$ & $144(77.8 \%)$ & $31(16.8 \%)$ & $5(2.7 \%)$ & $0(0.0 \%)$ & $0(0.0 \%)$ \\
\hline $\begin{array}{l}\text { Cold meats (frankfurter, bologna, ham, } \\
\text { sausage, salami) }\end{array}$ & $0(0.0 \%)$ & $60(32.4 \%)$ & $64(34.6 \%)$ & $54(29.2 \%)$ & $6(3.2 \%)$ & $1(0.5 \%)$ \\
\hline Sweets, bonbons, chocolate, ice cream & $2(1.1 \%)$ & $70(37.8 \%)$ & $69(37.3 \%)$ & $32(17.3 \%)$ & $12(6.5 \%)$ & $0(0.0 \%)$ \\
\hline Soda, industrialized juice & $0(0.0 \%)$ & $60(32.4 \%)$ & $71(38.4 \%)$ & $45(24.3 \%)$ & $9(4.9 \%)$ & $0(0.0 \%)$ \\
\hline Fried foods, pastries, snacks & $0(0.0 \%)$ & $19(10.3 \%)$ & $49(26.5 \%)$ & $102(55.1 \%)$ & $15(8.1 \%)$ & $0(0.0 \%)$ \\
\hline Margarine, butter, oil, lard & $1(0.5 \%)$ & $7(3.8 \%)$ & $1(0.5 \%)$ & $8(4.3 \%)$ & $115(62.2 \%)$ & $53(28.6 \%)$ \\
\hline Coffee and tea & $0(0.0 \%)$ & $1(0.5 \%)$ & $0(0.0 \%)$ & $1(0.5 \%)$ & $39(21.1 \%)$ & $144(77.8 \%)$ \\
\hline
\end{tabular}

\section{Conclusions}

The food access conditions are worrying and indicated that $57.8 \%$ (107) of the families are in food insecurity situation. The consumption of the settler families comprises mainly foods with high energy and low nutrient content, characterized by the low intake of fruits and vegetables and the introduction of processed foods with high energy density and sugar-added beverages, although the traditional dietary habits (rice and beans) are still present. This configures a diet at risk for important nutritional deficits, obesity, and many non-communicable chronic diseases.

\section{References}

Balem, T. A., \& Silveira, P. R. C. (2005). A erosão cultural alimentar: processo de insegurança alimentar na agricultura familiar. In Anais do Congresso da Associação Latino-Americana de Sociologia Rural, Porto Alegre, Brasil.

Brasil, Presidência da República, Casa Cívil. (2006, September 18). Lei orgânica de segurança alimentar e nutricional (Lei nº 11.346 de 15 de setembro de 2006). Diário Oficial da União.

Brasil, Ministério da Saúde, Secretaria de Atenção à Saúde, Departamento de Atenção Básica. (2012). Política nacional de alimentação e nutrição. Brasília.

Burity, V., Franceschini, T., Valente, F., Recine, E., Leão, M., \& Carvalho, M. F. (2007). Direito humano à alimentação adequada, no contexto da segurança alimentar e nutricional. Brasília: ABRANDH.
Corrêa, A. M., Escamilla, R. P., Maranha, L. K., \& Sampaio, M. F. A., 2004. Acompanhamento e avaliação da Segurança Alimentar de famílias brasileiras: validação de metodologia e de instrumento de coleta de informação urbano/rural. Campinas: UNICAMP. Relatório Técnico, versão preliminar.

Dombek, L. A. (2006). Autoconsumo e segurança alimentar em assentamentos rurais do Pontal do Paranapanema (Master's thesis). Faculdade de Engenharia Agrícola, Universidade Estadual de Campinas, Campinas.

Instituto Brasileiro de Geografia e Estatística - IBGE, Ministério do Desenvolvimento Social e Combate à Fome - MDS, Ministério do Planejamento, Orçamento e Gestão. (2010). Pesquisa Nacional por Amostra de Domicílios: PNAD. Segurança Alimentar, 2004/2009. Rio de Janeiro.

Instituto Brasileiro de Geografia e Estatística - IBGE, Ministério do Desenvolvimento Social e Combate à Fome - MDS, Ministério do Planejamento, Orçamento e Gestão. (2014). Pesquisa Nacional por Amostra de Domicílios: PNAD. Segurança Alimentar, 2004/2013. Rio de Janeiro.

Santos, J. V., Gigante, D. P., \& Domingues, M. R. (2010). Prevalência de segurança alimentar em Pelotas, Rio Grande do Sul, Brasil, e estado nutricional de indivíduos que vivem nessa condição. Cadernos de Saúde Pública, 26(1), 41-49. http://dx.doi.org/10.1590/S0102311X2010000100005. PMid:20209208.

Souza, A. M., Pereira, R. A., Yokoo, E. M., Levy, R. B., \& Sichieri, R. (2013). Alimentos mais consumidos no Brasil: Inquérito Nacional de Alimentação 2008-2009. Revista de Saúde Pública, 47(Suppl 1), 190s-199s. http://dx.doi.org/10.1590/S0034-89102013000700005. 
Souza, N. N., Dias, M. M., Sperandio, N., Franceschini, S. C. C., \& Priore, S. E. (2012). Perfil socioeconômico e insegurança alimentar e nutricional de famílias beneficiárias do Programa Bolsa Família no município de Viçosa, Estado de Minas Gerais, Brasil, em 2011: um estudo epidemiológico transversal. Epidemiologia e Serviços de Saúde, 21(4), 655-662. http://dx.doi.org/10.5123/S1679-49742012000400015. 